\title{
Doing Public Sociology in the Field-A Strong Sociological Intervention Project in China
}

\author{
Lina $\mathrm{Hu}$
}

Published online: 27 October 2007

(C) Springer Science + Business Media, LLC 2007

\begin{abstract}
Through the in-depth analysis of the features of Huabei rural industrialization, the unique factory regime in Baigou, Hebei, and the resulting special workers, this paper reveals two dilemmas the migrant workers in Baigou and larger Hubei area face: Because of the interpersonal network of labor market, personalized trade, familial labor process, and patrimonial management, the workers are unable to become either industrial working class or citizens. Facing this special group of workers, we still believe in their power of self-liberation. Drawing on Touraine's action sociology and sociological intervention, and Burawoy's public sociology and praxis-oriented research, we modify "sociological intervention" according to the reality of Chinese society and propose the methodology of "strong sociological intervention" whose vehicle is "Baigou Migrant Worker Night School." The night school provided workers with courses of labor law, English, and computer based on their actual needs. Labor law is the core to evoke the self-consciousness of the workers. Through communications in the night school and workers' real living circumstances, we collected their true information and treated it as the source of sociological knowledge. After three sessions of night school training, workers showed changes in skills, social, and psychological aspects, laying a foundation for the growth of self-consciousness.
\end{abstract}

Keywords Factory regime $\cdot$ Publics $\cdot$ Social action $\cdot$ Sociological intervention

It was the night of October 15th, 2005 when I entered my classroom and saw all my students already there waiting for me. They were gossiping with each other and laughing excitedly. "Hello everyone, " I said, " so nice to see you again in English class of our night school. Last week we have learned how to make friends with strangers. Now I'd like two students to perform the situation to help us review unit 2. Those who raise their hands first get to choose their own partner." A moment of silence occurred, and students began to look around the

L. $\mathrm{Hu}(\bowtie)$

University of California, Berkeley, CA, USA

e-mail: hulina55@yahoo.com.cn

说 Springer 
class. Several seconds later, a boy shyly saised his hand and walked toward a beautiful girl at the front seat, "Hello, my name is Li Jun. I am a worker from Liangdian factory. Nice to meet you!" The girl blushed and stood up slowly, "I am Chen Hong from Starlink factory. Nice to meet you too!' Suddenly the boy added something to everyone's surprise, "Shall we go to a movie together sometime?" All at once a blast of laugh broke out among the students... This is typically how our English lessons begin. All of these students are migrant workers from factories in Baigou. There are over 40,000 migrant labors working as bag makers in this small but famous township in north China, and our night school, an experimental public sociology project, provides them with basic training in English, computer and labor law. However, the night school project is not a charitable project but a project with multiple academic and practical considerations. Through the analysis of Chinese society and reflection of relevant theories, we $e^{1}$ proposed the method of "strong sociological intervention" to engage our target publics. By empowering and striking a conversation with the publics, we try to discuss the possibility of the growth of civil society in China, reconstruct sociological knowledge and society in the field, and enrich the theoretical and practical scope of a civil society.

Baigou is a township affiliated to Gaobeidian City, Hebei Province, China. It is located at the triangle hinterland of Beijing, Tianjin and Baoding city and it also intersects with Xiong County, Rongchen County and Dingxing County. It has 33 village streets, taking up an area of $54.5 \mathrm{~km}^{2}$, with a town district of $13 \mathrm{~km}^{2}$. Baigou is famous for its bag industry formed in the 1980s. After 30 years of growth, it has become the largest bag production base in northern China. The center of the regional bag manufacturing industry is based in Baigou Township, but bag production extends beyond Baigou Township to involve 4 adjacent counties, a total of 56 towns and over 3,000 villages that absorbed over 100,000 people working in the industry. In Baigou Township alone, there are 2,250 factories with approximately 40,000 migrant workers from 11 provinces in China engaged in the bag industry which constitute half of the whole population in Baigou Township. In 2005, Baigou Township's production value reached 2.2 billion RMB and its bag products sell not only to the 13 provinces in China, but also export to South Africa, Russia and South America. $^{2}$

There are two different types of bag factories Baigou. One is family factory and the other is standard factory. Family factories are prevalent and are of greater importance in Baigou Township. In Baigou and in the larger Huabei region, industrial practices and networks of family factories are rooted in traditional villagestyle social relationships. This overlap of industrial processes, traditional personal

\footnotetext{
1 "We" refers to the research team of public sociology project consisted of teachers and students from department of sociology, law school and micro-electronic institute in Tsinghua University, China. Professor Shen Yuan from sociology department is the leader of the team, and he is a devoted public sociologist specialized in labor and social movement study. This project is a team effort. The author was a student of Prof. Shen, and is now studying at University of California, Berkeley.

${ }^{2}$ Source of information: http://www.bdlyj.gov.cn/gaikuang/gaobeidian/g1.asp
} 
relations and social arrangements distorts our basic concepts of industrial production. Typical examples include:

Overlapping work and living spaces: factories are embedded in the family life and their layout follows that of the typical, northern Chinese style rural home. Typically, these compounds include a main entry gate on the southern side of the compound, a central courtyard, and a "U" shaped building arrangement lining the north, east and west walls of the compound. To meet the needs of the family factory, the row of rooms facing north are used as the living quarters for both employers and employees. The rooms facing west are the factory workshops, usually divided into a clipping workshop and sewing workshop, each with the necessary tools for production, such as sewing machines. The rooms facing east are the kitchen and storeroom. The gate into the compound is on the south wall. In this way, the layout blurs production space and living space, public space and private space.

Overlapping personal and labor relations: day-to-day labor relations are difficult to distinguish between interpersonal, even familial, social relationships. First, factory employers are often directly involved in day-to-day production. Second, factory employers eat, drink and live with their employees. In addition, in the past 20 years, many of these employers were farmers themselves (like their employees) and still choose to engage in the work of the day. As a result, the structural differences between employer and employee blur in day-to-day factory production. Add to this that few factory owners are educated in the basics of factory management, aboveboard market practices and relevant labor rights, it is an easy next step to make factory management decisions that work against the interests of their employees (such as regarding contracts, work hours, salary distribution, time-off, etc.). In addition, because employees feel close personal ties to their employers, they hesitate to raise issue with their working condition, rights as workers, etc.

Personalized market relations: although Baigou region has created a large-scale professional bag market, the trade in goods and labor is highly personalized. This is comprised of two aspects:

One is that the trade relations are personalized: factory stalls located in the central Baigou wholesale market are only used to exhibit bag samples, rather than instigate sales. Instead, the real trade is conducted between the factory operators and the middlemen "patrons" they have cultivated over the years. Because these relationships are highly personalized, factory owners often know little about the larger marketplace. The other is that the labor market relations are personalized: there is no formal labor market in the Baigou area. Instead, each spring festival, the employer asks the more senior employees to hire new workers on behalf of the employer and bring them from their hometowns back to the factory. This kind of "one consigns another" way of employing new workers has highly personalized the labor market. It also exacerbates the existing social inhibitions against workers speaking up for their rights.

Furthermore, the workers are separated apart according to their ethnicity and locality so that the bosses can rule them better (Tong 2005). As Dipesh Chakrabarty skillfully unravels, the resilience of prebourgeois consciousness explains the fragility of class identity and the salience of identities along lines of religion, language, race, or place of birth even at dramatic moments of conflicts between labor and capital (Chakrabarty 1989). 
Besides these family factories, there has been built a lot of standard bag factories with pipelining in recent years. Some of the standard bag factories are owned by foreign bosses from Korea, Russia and other areas. Standard factories usually possess commodious workshops, a large number of professional machines, brighter lights, and of course, hundreds of workers. There is always music on in the workshop, helping to cover the loud noises of the machines and release the tense atmosphere caused by fast production pace. Also we see monitors in the boss's office, supervising the work of the workers.

Therefore, due to the interpersonal network of labor market, personalized trade, familial labor process and patrimonial management, the workers are unable to become either industrial working class or citizens.

Baigou Township is the field in which we chose to practice public sociology, and its family and standard factory migrant workers constitute our target publics. Two questions emerge here immediately. The first one is: why do we choose Baigou Township as the field? The second is: how to engage this particular public? To seek the answers, we must above all place the field and the public in a boarder theoretical framework and in a larger picture of China and the world.

\section{Theoretical and Practical Inspirations}

In 2004, the theme of American Sociological Association Annual Meeting was "Public Sociology". In 2005, the centennial, the meeting was centered on "Comparative Perspectives, Competing Explanations: Accounting for the Rising and Declining Significance of Sociology". This year, the major topic of the meeting was "Great Divides: Transgressing Boundaries" while in 2007, people will be discussing "Is another World Possible? Sociological Perspectives on Contemporary Politics". From this trajectory, there is a clear tendency that sociologists worldwide have began to focus their attention on the fate of society and sociology in an era of fast transforming world. Tons of works has been written to address the urgent call for a civil society, and some have proposed very insightful ideas and methods of realizing it, including several interesting experiments.

We are now in consensus that creating a civil society is our ultimate goal and that our discipline needs to transcend itself beyond its academic boundary to be a public knowledge. However, the question is: how to create a true civil society? There is no way for us to recreate a world or produce a population coming out of nowhere to constitute this ideal society. Hence our hope is on the current world and people rooted in a continuous history of human society.

By developing the historical analysis of marketization process discussed by Polanyi (1944) in his famous "The Great Transformation", Burawoy has weaved a new picture of capitalist trace in terms of marketization period, fictitious commodity, object against, right invoked, corresponding property of sociology and concept of science illustrated in Table 1.

This table beautifully highlights the evolvement of capitalist history as well as sociology, providing us a penetrating theoretical lens for understanding the world behind us and the future awaiting. In the first wave the destructive power of markets was countered by local communities that hung onto labor rights enshrined in custom 
Table 1 Three waves of marketization and sociology

\begin{tabular}{|c|c|c|c|}
\hline & $\begin{array}{l}\text { First wave of } \\
\text { marketization } \\
(1850-1920)\end{array}$ & $\begin{array}{l}\text { Second wave of } \\
\text { marketization } \\
(1920-1970)\end{array}$ & $\begin{array}{l}\text { Third wave of } \\
\text { marketization } \\
\text { (1970 onwards) }\end{array}$ \\
\hline Rights against the market & Labor rights & Social rights & Human rights \\
\hline Social defense against the market & Local community & State regulation & Global civil society \\
\hline Contribution to society & Utopian sociology & Policy sociology & Public sociology \\
\hline Unifying principle & Vision & Object of knowledge & Standpoint \\
\hline Science & Speculative science & Pure science & Value science \\
\hline
\end{tabular}

and practice rather than a system of law. As the second wave of marketization eroded labor rights, it generated a countermovement. This time it was states that would regulate commodification, restoring labor rights but also promoting welfare or social rights. And today, nation states no longer contain markets; instead they unleash them through deregulation of industry, privatization of public services, and the reversal of both labor rights and social rights. Once again society has to spring to its own defense, drawing on its own resources. This time the scope of societal self-protection is not confined to the local or national but extends to the global. Accordingly, the language of its defense has to be universal-the language of human rights, of selfdetermination that includes both labor and social rights (Burawoy 2005a).

Here we are standing at the front edge of the third wave of marketization. Given the gap between the sociological ethos and the world we study, sociology is propelled into the public arena where public sociology becomes an inevitable pressing cause. Through the fine analysis of the four different but intertwined types of sociology - professional sociology, policy sociology, critical sociology and public sociology, as well as their configuration variation from country to country, Michael Burawoy has reminded us to take a close look at the national contexts before we apply public sociology to any specific society.

\section{Locating China}

After 30 years of reform and opening to the outside world, China has achieved spectacular economic development that amazed the globe. However, in sharp contrast, its political system has remained almost the same. People's living standard is enhancing, but they choke in a tight political atmosphere where there is no equality, democracy, freedom and civil right which are generally considered concomitants of market economy. What underlies the combination of "economic miracle" and "institutional miracle" is a marriage between the highly centralized state and the fast developing market (Shen 2006a). Though all too often, market and state have collaborated against humanity in what has commonly come to be known as neoliberalism, it is a post-communism we face in China which exhibits many idiographic characteristics. This has posed tremendous challenges for the theoretical logic of our discipline and for the people living in it trying to make political changes.

Before we make any move, we need to rightly locate china in a map of human history and theoretical framework. There is one word that can best characterize china today - "transformational". However, the transformation of china is a very complex Springer 
and amorphous one, and it is quite different from any other countries. The transformation of China at least contains the following distinctive aspects:

As regards historical period, China is now at the intersection of three waves of marketization. Its labor, money, land and environment are being comodified all together in such a fast pace that we departed from a "shortage economy" termed by J. Kornai to a market economy oriented "wealthy society" in only 30 years, accomplishing what took other countries hundreds of years to fulfill (Shen 2006b). The mixed marketization is definitely a crucial important reason why China has achieved so rapid economic growth, but it's also the reason why people's labor rights, social rights and human rights are being intruded entirely as we will see in the following section. Where we are heading for still hangs in doubt.

As regards the production way, China is at the convergence of two great transformations... Polanyi used the term "The Great Transformation" to refer to the transformation from feudalism to market economy. His extraordinary theoretical contribution also lies in what he called "double movements"- the coexistence and contradiction of self-regulated market expansion and self-protection of society. Writing The Great Transformation in 1944 he imagined a socialist world in which market and state would be subordinated to the self-organization of society. He was overly optimistic (Burawoy 2006). Based on Polanyi's viewpoint, Burawoy brought forward the concept of "the second great transformation" to refer to the transformation from socialism to capitalism, drawing on the evidence that former socialist countries began to embrace capitalism. Hence for China, as debris of feudalism still remains while socialism is still ruling the country at large, its way to capitalism is destined to be a double challenge.

As regards the relationship between state, market and society, we see a happy matrimony between state and market, but we can't find a civil society growing within. By civil society, according to Sociological Marxism, we mean an active society which is against a self-regulated market in Karl Polanyi's terms, and a civil society which is against state in Gramsci's terms (Burawoy 2003).

As regards social structure, China is becoming a cleaved society (Sun 2003). It manifests in three aspects. First, on social hierarchy and stratification structure, the bipolarization is becoming more and more severe but there lacks an effectual mechanism of integrating different classes and groups. Second, a cleavage occurred between city and the country. It embodies two facets. One is that rural residents and urban residents belong to two different social classes, and the other is that there is a great gulf fixed between rural regions and urban regions. Third, cleavages exist on many levels of cultural and social life. The essential of a cleaved society is that ingredients of different epochs coexist but there is no organic connection between them.

As regards class structure, globalization has produced the largest-scale of working class in China. After the reform and opening to the outside world, as Chinese economy integrates with global economy, China becomes an important part of the world-wide manufacturing industry, and the industrial worker troop of China also gets huge development. When international society is in consensus that China is becoming a "world factory", its sociological implication is: China is forming the largest scale of industrial working class around the world. This burgeoning working class has two sources: Firstly, there are workers from former socialist state-owned enterprises, and secondly there are migrant workers. About their quantity, there is no 
accurate figure yet. According to official document, there are approximately 230 million industrial workers in contemporary China.

As a special group, migrant workers have contributed a lot to the city development. Nonetheless, for a long period of time, they are discriminated and disdained by urban residents. The word "migrant worker" is usually linked to mess, violence, instability, theft and robbery. These migrant workers leave their hometown to enter the secondary labor market in the city, doing things that urban residents are unwilling to do, working in the most dangerous environment overtime while getting the least payment. They live in tabernacles or cheaply rented houses, prohibited to use public infrastructure, and their children are repulsed from attending council school. Most of the migrant workers enjoy no insurance at all, and many of the factories they work in lack necessary labor protection equipment, causing numberless industrial injuries and occupational diseases. When accidents occur, they have no way of getting compensation without formal contract or insurance, and the families depending on them would collapse soon, facing extremity. Or in one word, their labor right, social right and human right are invaded completely.

As regards sociology, after the rebuilding of the discipline with the help of American sociology at the beginning of 1980s, the first generation of Chinese sociologists were able to carry out basic social investigation and research. However, it wasn't before long that people found Chinese sociology in profound paradox. For one thing, on the production of "problematic consciousness", when sociology was supposed to possess the macro vision of grasping social institution and class reformation in face of the great social transformation, it encountered "postmodernism", accepting sociological thinking fashion of "micro-practice" and "fractalization"; for another, in the respect of theory and technique, when sociology was supposed to develop theories and methodologies measuring the drastic social change, it embraced the theories and techniques of gauging stable society. Thereby the reality is: people are studying occupation stratification in the era of new class formation; people are studying stable structure in the era of intense social conflicts; people are studying labor outside the labor process framework while people are emphasizing the "value free" principle facing the suffering of the bottom society. In this way, it asphyxiates the imagination of Chinese sociology, rendering its "dislocation" (Shen 2006a). Or we may say that Chinese sociology has a short and weak triumph of professional and policy sociology, though critical and public sociology has been around at a fringe producing low but counter-voice.

Now envisaging the great transformation of Chinese society, it is time for us to bring sociology into a conversation with publics, understood as people who are themselves involved in conversation and therefore entail a double conversation; it is time for us to make visible the invisible, to make the private public, to validate these organic connections as part of our sociological life (Burawoy 2005c); it is time for us to work in close relationship with the publics to trigger internal interaction, to constitute movement or organization, and to change the current system. Public sociology has broken fresh ground on which sociologists can plough and sow, and we are in an advantaged position of reconstructing our society and our discipline.

Although sanguine about a bright "public" future, and indeed Burawoy has offered us a key to the door of civil society, we still have to grope for the right door as there are so many doors with different paths leading to different ends of civil 
society. Just as Burawoy noted, public sociology has no intrinsic normative valence, other than the commitment to dialogue around issues raised in and by sociology. What we are fully aware of at present is that our theoretical and practical ambition is to create and foster a civil society in China and we need to realize our goal in the guidance of public sociology, especially the organic kind. But who constitute our publics? Which method is more feasible and effective in fostering publics? And what concrete means shall we adopt to build a civil society under the collusion of market tyranny and state despotism? The answer to the first question is relatively clear. In the United States, public sociologist are in the business of fostering such publics as the poor, AIDS, single women, gays and so on not to control them but to expand their powers of self-determination. Analogously, we choose the most marginalized and oppressed groups as our immediate publics to foster not only because they are large in quantity, but also because they are the most potential actors desperate to change their life circumstances. Among these publics, migrant workers form a very important part. As Anthony Orum and Arlette Grabczynska described, migrant workers are subject to arbitrary abrogation of their rights, no wonder that they are often the first to form unions - whatever their legal status. On the other hand, we insist that the industrial working class has made significant and selfconscious interventions in history (Burawoy 1985). So as migrant workers become a new member of industrial working class, we believe in their power to reshape the world. However, the answers to the latter questions still lie in the distinctive features of China itself.

\section{Strong Sociological Intervention}

The penetration of the state into all realms of life did not extend a public sphere so much as negate it, for without attachment to the party or one of its subsidiary organizations no particular individual could make claims with any general validity. For the everyday citizen there was little space for politics because everything could be politicized and affairs of heart and hearth be treated as affairs of state. (Nee and Stark 1989) All the relations concerning power, domination and oppression are obscured by the state, imposing an invincible structure upon atomized individuals. To create a civil society, the foremost issue is to unearth the real relations of the present society and convert the atomized individuals into dynamic actors to transform the structure.

Here enters Touraine (1965) who contends that sociology studies social relations. He assumes sociology's main method to make possible the direct observation and analysis of the relations masked by order and domination, so as no longer to be the dupe of categories of social practice. This then presupposes the active intervention of the sociologist whose task is to bring out these social relations concealed behind a mesh of approved and organized practices. He makes social movement the central problem of sociology because social movements are at the heart of an analysis of how a society makes itself. He contrived sociological intervention method to conduct research on five different movements: the trade union movement, the student movement, the women's movement, the Occitanist movement, and the antinuclear movement. The intervention is carried out on a group of rank and file militants involved with the self-analysis of their movement based on their confrontation 
with opponents or partners. These groups spend many hours reflecting and examining the nature of the struggle they engaged in and, under the probing questions of the research team, raise their consciousnesses. Sociological intervention is actually an analysis of the self-analysis of a group of social movement participants.

Touraine (1987) proposed four principles for sociological intervention. First, we must enter into a relationship with the social movement itself; second, we need to go beyond ideological language and to apprehend the group in its militant role; third, we should set the social movement in its context, and cause the societal and cultural stakes of a conflict to emerge by speaking to both sides; and last, the researcher performs two functions, one as agitator, and the other as secretary. The researcher will transform his observation of the actors into social action theory to enhance the ability of the actors. The objective is to create a research situation that would be able to represent the nature of the struggles. Intervention helps the actor to shake free of the constraints by which he is surrounded, to extend his field of analysis and become more capable of action. The function of intervention is to establish as prolonged as possible an exchange between action and analysis - thereby stimulate a permanent sociology. Touraine (1981) is at his best elaborating the self-analysis part which include four crucial flexions that transform witness or confrontation group to image group and then to analyst group, turning actors to analysts who would finally become a better actor.

Touraine has offered us some useful methods analyzing social movement. However, his action sociology and sociological intervention is against the programmed western society that is quite different from China. For example, there are few militants in China, not to mention social movements. Even if we are able to conduct research on some of the movements, we find out that the militants are willing to be a part of it while the interlocutors or the opponents show indifference or even contempt to be involved. This is so because the two sides are at such an imbalance of power field. The militants treat researchers as their listeners rather than researchers to share their pain, frustration and desperation caused by struggle with the powerful opponents. And even if we do manage to invite the two conflicting groups to be at the same room to carry out sociological intervention, we discover that the meeting schedule prescribed by Touraine is so prolix (12 to 15 meetings, each lasts 2 to $4 \mathrm{~h}$ ) and complicated that people who attend all lose interests in participating in it pretty soon (as in the case of sociological intervention in urban movement in China). Does it mean that sociological intervention is not applicable to China? No, it's just the opposite. The way to create civil society is by changing the current political system, the way to change the current political system is by making social movements, and the way to make movement is by realizing the power relationship first. Sociological intervention has provided us a methodological concept that we need to reveal the social relations veiled by domination and that we need to develop a systematic research agenda to raise the consciousness of the actors to take action. The dissimilitude is that Touraine's sociological intervention is to awake the consciousness which lies in somewhere within the actors while a sociological intervention we need is to foster the consciousness which is not so much existing within the actors.

Due to the particular institutional division between city and the country, "production of society" in China is a very asymmetric process. The new-rich class and middle class formed since the reform and opening to the outside world have a relatively faster growth of self-organization mechanism while in the subaltern 슬 Springer 
society, the self-organization mechanism is stagnant owing to the united inhibition of power and capital. Therefore, according to the different degrees of self-organization, we develop the concept and method of "sociological intervention" into two categories. We entitle the first category "weak sociological intervention" dealing with the well self-organized group. In this category we can by and large use the sociological intervention procedure proposed by Alain Touraine. We entitle the second category "strong sociological intervention", dealing with the poorly selforganized group. The objective of the "strong sociological intervention" is a dual one: it is not merely for the production of sociological knowledge, but also for the reconstruction of society itself, attempting to meliorate the actor's work and life (Shen 2006b). This is a whole new territory, and we have to search for a disparate way of exploring it.

To use Touraine's terms, we also need some critical flexions that turn the unconscious group into conscious group and then to self-organized group. The first three principles of sociological intervention are of great importance to achieve this goal, but the last one- the objective role of sociologist would inevitably jeopardize our cause. As an upper-class sociologist, Touraine has emphasized for many times that sociologist must keep a certain distance from the group he is working with and locate himself outside the movement. However, seeing the tribulation of the populace and all kinds of unequal social arrangements, not taking position already implies a certain position. Therefore, we must modify sociological intervention with moral stances before we apply it to China.

This is where and why we invite liberation sociology in. Liberation sociology's major concern is to raise consciousness among the oppressed. It challenges the selfdelusionary notion of objectivity. It also offers a new, radical interpretation of classical theorists, a critique of much of sociological theory (especially functional theory), and a lot of cases of sociologists practicing liberation sociology in the field. By reflecting sociology history, it reminds us of the original spirit of sociology to yearn for a better world. Liberation sociology is an activist rather than a purely academic sociology. That activity is not on behalf of the oppressed, but is achieved by learning to see the world from their perspective and joining with them, adding our sociological theories and methods and data to their anti-establishment arsenal (Deutscher 2002).

Feagin and Vera (2001) have stated sociologist's moral stances so well in liberation sociology that we directly borrow its core ideas to revise Touraine's version of sociological intervention. Liberation sociology accentuates that as researchers we must take sides with the oppressed people, making their daily life and experiences a source of knowledge; also we are obligated to make the problems of oppression, domination and inequality as the core concern, and reveal the underlying social structural cause for inequality; sociology is essentially reflective and researchers should emphasize the importance of community based empirical research; the last and the most important point is that we don't only talk about liberation, we actualize it.

About the detailed strong sociological intervention method and procedure, HsiaoChuan (2003) has presented a referential approach called praxis-oriented research based on the "foreign brides' literacy programs". It illustrates how the concepts and 
techniques of the "theater of the oppressed" can be applied, with the use of transformed traditional research methods, to empower the marginalized groups. It is proposed that praxis-oriented research can achieve more sophisticated research results, because by actively involving oneself in the process of social transformation, the researcher can observe and examine much more directly the mechanisms of social construction and transformation. The core information is that we can empower the oppressed through education, and by reconstructing researchers themselves, we can get at a much more profound understanding of the oppressed and ourselves. This is in accordance with Paulo Freire's claim that our purpose is not only to help the illiterate to read and write, but also to help them understand critically about the reality of society so as to change it (Freire 1970).

All the theories above share the following essentials that they all take civil society as the ultimate destination; they are all critical about classical theories and current system; they all emphasize the dimension of action and empirical research (especially community based); they are all in support of social movement; they all try to empower the oppressed; they all stress a dialogue or exchange between the researchers and their publics or objects of study; and they all have proposed the role of sociologist (though different from one another). These essentials constitute the starting point of our very own project.

\section{Doing Public Sociology in the Field}

Finding the Right Field and Public

To conduct our project, we must first find the right field. By "right" we mean that we need to find a locale with all the distinctive features that China represents as we listed earlier. And since national state becomes more socially irresponsible, its burden is downloaded onto the locality. Perhaps at the local level where municipal administration is more sensitive to the needs of its citizens there is more scope for sociological intervention (Burawoy 2005b). Taking all elements into consideration, we think Baigou Township located in Hebei Province is a perfect choice so far.

From the characteristics of Baigou discussed in the first part of this article, we can see that due to the intersection of three waves of marketization, Baigou migrant workers' labor right, social right and human right are all eroded in the same space time; being at the convergence of the two great transformations, the new emergent capitalist way of bag production is either embedded in traditional social arrangements or associated with socialist way of intervention (for example, the local government); here again, we encounter a very strong coalition between market and local government (symbol of state at local level), but there is no sign of a civil society; the shape contrast between the rich bosses and impecunious workers, between the local residents and migrants, between conditions of standard factories and family factories, and between the vast cropland and contiguous high buildings and modern malls represents a terribly cleaved society; globalization has brought so 
much foreign capital and so many orders to Baigou that it draws numerous migrant workers from all over China to engage themselves in the bag industry, forming a large-scale industrial worker troop... It seems that Baigou is a fair representative of all the distinctive features of China today.

We choose the migrant workers in Baigou as our target publics out of two considerations. One consideration is that these migrant workers are the most oppressed group in China. After reform and opening to the outside world, compared to other social groups in the city, workers are relatively weaker; compared to the workers in the city, migrant workers are relatively weaker; compared to the migrant workers who work in the city, the migrant workers working in the rural area like Baigou Township are relatively weaker, for capitalist employment relations are veiled by traditional village and family arrangement which deprives the workers of their right to protest. Therefore, they need our support most. Another consideration is that beginning with the most oppressed group, any progress would be notable so that we can better evaluate our project.

\section{Opening the Door, Getting Into the Field}

Although Baigou Township is a very good choice for conducting our sociological intervention, it has a very tough "gatekeeper"-its village and family are like a double bulwark to prevent researchers from outside to walk into their world. As many ethnographers wrote in their books, luck plays a very important part in getting into the field. And we were lucky in that sense.

In winter, 2002, six female migrant workers died of poisonous benzene contained in tinpot glue water in Baigou. This tragic incident has aroused a great deal of report by media and attention of publics and government officers. The responsible officers were dismissed, and the working conditions of family factories were scrutinized. All these provided us an opportunity to break the rampart of village to enter into the family factories. Under the financial support of Dutch Embassy's "ChinaNetherlands Law Support Project" and "Chinese Law Development Support Corporation", we designed and carried out a "Sending Medical and Law to Village and Family" project in Baigou. In this project, we established a team consisted of teachers and students from sociology department and law school in Tsinghua University, as well as doctors from Beijing Armed Police Unit No.2 Hospital. We organized manpower and material resources to offer free physical examination for migrant workers in family factories. When the migrant workers were waiting in queue for their physical examination, we dispensed leaflets and brochure with basic labor law knowledge to the workers in hope that they would use "labor law" to protect themselves. We also set up a medical file to record their detailed information including their age, hometown, gender, years of work in Baigou, type of work and their health status. Taking the advantage of the direct contact with these migrant workers, we educated them with four fundamental categories of labor law, namely contract, wage, work period and right of rest. For a whole year from March, 2002 to March 2003, we entered 26 village streets of the 33 village streets affiliated to Baigou Township, providing 1783 migrant workers with medical, law and social service. For us it was a successful start because first, we entered these family 
factories and got to know more about the migrant workers' daily life; second, by the dissemination of "labor law", we helped the migrant workers begin to be aware of their right and third, we created a chance for the segregated workers from different factories to communicate with each other.

Although "Sending Medical and Law to Village and Family" has achieved some good results, it at most performed the function of "enlightening" the migrant workers. However, it does pave the way for us to establish a long-term and institutional project in Baigou Township (Shen 2006a).

\section{Breaking Two Myths, Empowering the Oppressed}

Today, the fast developing world along with the ideology of highly centralized Chinese government has created two myths for all the people, especially the underclass. In an era of high-technology, if one doesn't know how to use computer and in an era of globalization, if one doesn't speak English, then this person is deemed to be illiterate and useless. This is exactly how a great many people feel about themselves - anachronism, far behind the world, the epoch, and other people that they are doomed to be ostracized and silenced. In most cases, these people blame themselves for not learning enough. It is a fact that they don't know anything about computer or English, but what they are really ignorant of is that it is not an individual fault but a blunder of the structure. It is a problem caused by structural inequality not by personal endeavor. What they don't know either is that if they are determined to learn, they can also master computer and English. The reason why computer and English seems so intimidating for them is that they can't afford to learn (be it money, time or energy). To raise the consciousness of the oppressed and build their self-confidence, the pre-requisite is to break the two myths. And this presupposes our unique way of strong sociological intervention-a night school project for empowering the most oppressed group in China.

\section{Experiment of Night School}

To break the two myths and empower the oppressed, we had to create conditions for the migrant workers to learn English and computer. A school was usually a best choice for implementing systematic education, and regarding the actual circumstances of the migrant workers in Baigou, a night school was perhaps an appropriate mode. By delivering relevant knowledge through night school, not only would we be able to break the two myths and build confidence for the migrant workers, we could also enhance their working and living capacity, increase their market competency and prepare them for rapid technical and social changes.

Besides, for migrant workers, to receive some information of labor law while they were waiting in queue for the physical examination is definitely not enough. To keep the continuity of intervention on the same group of migrant workers, we needed a more stable organizational form. Now that there was no way of setting up an autonomous trade union, night school might be a feasible option for achieving stable organizational form.

Moreover, in order to increase the self-organization ability of local migrant workers, they needed to communicate with other migrant workers from different 
villages and factories spontaneously. Coming to study together in the night school was a channel for them to connect.

Finally, in the long run, if the migrant workers are to gain self-organization ability, there must be a certain number of active militants. And night school would be a seedbed for fostering these militants.

After 7 months of preparation, we set up a Baigou Migrant Worker Night School in the township district. This was because many family factories were settled in here, and it was easy to engage the migrant workers from neighboring villages.

There were two classrooms and one teacher office in our night school. One of classrooms was altered into computer room, equipped with one sever and 20 computers. The other one was regular classroom with four rows of desks. The two classrooms could hold 50 workers for lessons at the same time.

In the night school, we offered three courses: labor law, English and computer. Labor law was the core course. English and computer courses were offered to break the two myths, but also they served another important function too. They were the icing of the core course. According to our experiences, in a local society like Baigou, only giving labor law lessons would incur the deprecation of family factory bosses, and the workers themselves often wouldn't understand - they used to treat labor law as something related to the "formal workers" in cities which had nothing to do with the "informal factory workers" in a rural area like themselves. So we came up with the idea of "sandwich class" that we arranged labor law class between the English class and computer class. On the one hand, it would reduce the radicalism from the perspective of the bosses; on the other hand, it could add to the interest of workers to come and study.

All the teachers were from sociology department, law school and microelectronics institute in Tsinghua University. Labor law lessons were taught by Mrs. Jianming Chen and her six students from law school; Computer lessons were taught by Xiaohui Lin from Micro-electronics department, and I was the English teacher.

The teaching materials for all the three courses were written and edited by graduate students from the above-mentioned departments and institute in Tsinghua University according to the migrant workers' knowledge structure and daily life. For instance, our English textbook is consisted of 10 units, and every unit is composed of four parts: basic sentences, dialogue, grammar and vocabulary. We picked up all the content from the everyday life of migrant workers, including their family, hometown, factory, work, coworkers, life, etc. We also had inserted many pictures and comics in the teaching materials, making them seem much easier and more intimate.

\section{Classes in Night School}

Baigou Migrant Worker Night School was launched on October 7th, 2005. It opened every Friday and Saturday night from 7 to 9 o'clock with every class around $40 \mathrm{~min}$. Before the class, we always asked the workers to register in the teacher's office first so that we could collect the basic information of the workers and check the rate of their attendance. Then we divided workers into two groups. One group of workers listened to computer class and the other group of workers listened to English class simultaneously. After the first class, all workers gathered 
in the same classroom to listen to labor law class. When the labor law class was finished, the workers would be divided into two groups again, listening to a different class from their first one.

\section{Labor Law Class}

Law labor was the core class designed to help the migrant workers build their consciousness of "right". Labor law class was given in the computer room which was bigger than the English classroom so that all the students could be seated together. Each labor law class, I would sit in the classroom to observe the circumstances of the class and reactions of the students.

Since labor law was the most sensitive class, some bosses also came to the classroom, not for the sake of learning basic labor law provisions, but mainly to monitor their own workers. The first labor law class was about wage. A lot of workers seemed expressionless and lost as their bosses sat there playing with computer. As time went by, the students began to show interest. One sign was that they were listening much more carefully to the teacher than they used to be and they were reading the teaching materials according to the class theme. Occasionally we could feel that some students wanted to ask the teacher questions or express their ideas, but because their boss was present, they often kept silent.

A turning point occurred when Mrs. Jianming Chen gave a lesson to the class. Mrs. Chen was a highly qualified law teacher in Tsinghua University, and she was also experienced in dealing with labors. In her class, she started with migrant workers' daily life to elicit the law issue, explaining detailed law content with concrete cases. It was obvious that using real pertinent cases to disseminate labor law knowledge was the best way. From then on, labor law class turned into a caseoriented class, appealing to more workers.

On November 18th, 2005, we witnessed the first idea exchange between teachers and students. When asked what the minimum wage was in Gaobeidian City, students were active in telling us what they knew. Some said the minimum wage was 400 , some said 470 , and others said different numbers. Their diverse answers implied that they did care about their wages, but they just didn't have the access to the right information. So we told them that the minimum wage there was $470 \mathrm{RMB}$ a month and if they were underpaid they could sue their bosses. Then we discussed relevant policies and compared them with policies in big cities. The students seemed very happy in knowing what they should have known a long time ago.

In the process of teaching, we learned that many students were using bogus identity card and didn't sign any contract with their bosses. Most of them didn't have any insurance either. What was peculiar about the insurance in Baigou was that in one factory, bosses would purchase insurance for approximately $10 \%$ of the workers. And whoever got injured during the work process, he could fake to be one of the $10 \%$ workers with insurance to go to the hospital. However, if the accident ascended to law level, the bosses had various excuses to escape their legal responsibilities.

Sometimes, we touched sensitive issues that annoyed the bosses, and they would stand up and argue with the teacher and students. For example, there was once a debate on contract in the probation period. Usually when a new worker came to work in a factory, the boss would not sign any contract with the worker until he 严 Springer 
worked there very well for at least a month. Many worker students in the classroom complained that they were often underpaid for this month and unemployed after the probation period was over. What was even worse was that for the novices it was very likely to get hurt and the boss would take no responsibility of sending them to hospital for therapy. The bosses would refute that they did so because they needed to know whether this worker was worth hiring and training and that some of the new workers were considerably instable in that they ran off to other factories or went back home during the probation period. This was dramatic moment for both bosses and workers. By listening to the argument, the workers got to understand the standpoint of the bosses which was often obscured by interpersonal relationship. They were then in an opposition to the bosses collectively, regardless of their factories and origins. And it was exactly what we were looking for, a situation created for emerging the conflict and cultural stakes. Our teacher also participated in the dispute and then explained the whole issue in the light of law, mostly supporting the workers.

Step by step, students began to ask teacher questions about protecting their right, including contract, payment in arrears, industrial injuries, and so forth. And we tried our best to help them. We also left them with our law clinic telephone number, telling them to call whenever they have problems. And some of them did call and were helped by us.

\section{Computer Class}

Computer class was probably the most attractive class in the night school. Bosses might oppose labor law and some people might find English distant or a little difficult for them, but almost everybody liked computer class which could bring them fun and link to the outside world.

Computer class also began with the fundamental knowledge. To help the students be accustomed to using mouse, we taught them how to play games like "removing land mine" and "card". These two games called for very high sleight on mouse use, and the games themselves were fun for the students. By using this method, most students got familiar with mouse rapidly.

To extend students' imagination as well as to help them further be up on mouse use, we picked up painting as a teaching section. The teacher just instructed the students how to use all the tools in the paint program and then asked everyone to paint with the computer whatever they wanted. To our surprise, all the students had created something really fascinating of their own. Some painted beautiful houses, some designed new bag styles, and others portrayed their friends. We printed every picture out and held a small exhibition. The students were exhilarated to see their own production appreciated by so many people. After the exhibition, we complimented away the pictures to their owners, and rewarded the students with teaching materials. It greatly exalted their enthusiasm.

Another important part of computer class is typing. Our teacher taught the students how to type both English and Chinese, and then gave them enough time to practice. The text we offered to test the typing speed of the students was mostly about labor law. We combined labor law information, English and computer typing practice together in hope that they could learn more about labor law and English 
while increasing their typing speed. When students got proficient in typing, we asked them to write whatever they would like to write about on the screen. Then we saw letters to their families, reflections on today's work, experiences working in Baigou, protest against bosses, essays and poems, and even love confessions which offered insights for us to know more about their true life and feelings. In the last lesson of typing, we held a class contest, and everybody was zealously involved. At the end of the competition, we awarded the winners with souvenirs of Tsinghua University.

A climax in computer class occurred in the Internet part. Many workers, especially male workers, went to net-bar to explore the Internet before they came to the night school. However, their activities on the Internet were limited to entertainment such as listening to music, seeing movies, chatting with friends and playing games. Our main objective was not to offer these students a free place to surfer the Internet for fun, but to guide them to search relevant information for protecting their right and communicating with colleagues and outside world for support. Hence, our content was centered on using search engines (Google, Yahoo, Baidu, etc.) to seek pertinent information, checking news domestically and overseas and applying for e-mail boxes to communicate with others. We also wrote all the teachers' e-mail addresses on the blackboard so that whenever the students had any questions, they could send us e-mails and ask for help.

\section{English Class}

As the English teacher, I'd like to talk more about what happened in English classes.

We found out from the registration that the workers who enrolled in our night school had very different educational levels - some of them graduated from high school, some graduated from middle school, some failed to graduate from middle school and others just finished elementary school - so we made a very simple test on their English level, asking them to write down the 26 English letters. What surprised us was that the workers' English basis was awfully poor (though most schools offer English lessons since the first year of middle school in China), and only two students could remember all the 26 letters. Facing this situation, we decided that English class must start from zero, and that we should stress on listening and speaking part.

In the first class, workers sitting in the classroom all seemed shy and nervous, and many of them were afraid that their basis was too poor to understand the lessons. So, I didn't start teaching English immediately but instead gave them some psychological comfort. I first friendly introduced myself to them, sharing with them my experience of learning English, especially the difficulties I encountered and the process of conquering them. I kept smiling and told them that as long as they were determined to learn English and worked hard, they could make it. The students then seemed a little relaxed and more confident.

The first part of English class was learning new words. Each time, I wrote all the new words on the blackboard with their Chinese meaning beside. Then, I explained the meaning and usage of every new word and emphasized their pronunciation. Sometimes the students were amused by my exaggerated mouth shape used to demonstrate how to pronounce the words correctly. Afterward, I asked them to read after me word by word for three times, and read each word three times again without my leading. When most students had memorized the new words, we moved on to the grammar, sentences and 를 Springer 
dialogue part. The procedure of learning grammar and sentence part were similar to the new word part, while the real challenge was the dialogue section.

Dialogues were always rooted in a situation. It was the key to evoke the workers' imagination and potential to act. Initially, after the students got familiar with all the sentences in a dialogue, I asked the students to practice the dialogue with their deskmates. However, I found this method not working well because many workers were from different factories or different places; they didn't know each other and were not comfortable with strangers. Also they were very anxious about being asked to answer any questions individually. Therefore, I changed my strategy of practicing dialogues and asking questions. When it came to the dialogue part, I would divide the class into two groups. One group played role A and the other group played role $\mathrm{B}$, then exchanged. In this way, dialogue practice became a group conversation, everybody got active and excited, and the two groups would compete with each other which added to the loudness of voice and atmosphere of learning. As for asking questions, I would start with the whole class and then focus on individuals. For instance, Unit Two "Meeting People" offered a very typical and important life scene as well as a good chance for the students to know their fellow classmates. To avoid stage wait, I didn't directly ask anybody's name but told everyone to answer my questions collectively. The outcome was, when I asked "what's your name", students were very consistent in saying "My name is" but created a farrago of their own names. It sounded so funny that all students laughed. Seizing this opportunity, I asked the students one by one: "Sorry, what's your name again? I didn't hear it clearly just now". At this time, they became quite freehanded and told the whole class loudly and fluently their own names. It was a huge progress.

After the students got more familiar, I added stage performance to promote their English skill and enhance their ability of creating situation and acting. As I expected, many students were too shy to be on stage at first. So I encouraged some students who appeared more active in the foregone classes to go on stage for performance and asked all other students to applaud for their bravery. When they finished their performance, we would reward them with louder applause and favorable smiles. It did work. Those who had been on stage showed more interest and confidence in learning English. And I tried my best to give every student the equal chance to perform. After a period of time, students fell in love with stage performance, and our English class was full of applause and laughter.

What excited me more was that students started to express their ideas and ask questions. Once in a class, I taught the students that when we first met someone, we could say "How are you". Suddenly a student sitting at the back raised his hand and said "We can also say "How do you do"'. Pleasantly surprised, I praised this student and taught the class other ways of greeting too. Another time when I was writing new words on the blackboard, I missed a letter in a long word and several students noticed and pointed it out. Instead of being embarrassed, I was extremely happy because it indicated that the students not only had mastered the word, but also they dared to bring forward their opinion and question the "authority" (teacher in this sense).

During the process I discovered that encouragement and praise were very important in inspiring the migrant worker students who were seldom accredited by other groups of the society. Our goal was to foster the subjectivity of the migrant 
workers, and building their self-confidence was the first step. Besides promoting the students' English ability, enhancing their communication capacity, establishing a trust relationship between researchers and these migrant workers, English class was also significant in collecting data that otherwise wouldn't be done.

In a class about number and age, when I asked the students directly "How old are you", they all would reply "I am 16", "I am 17" or even older. However, when I asked the same question in a different way, like "When were you born", some of their answers were "I was born in 1991", or "I was born in 1992". For the same person, how could he or she be 17 while he or she was born in 1991? As we observed in the registration process before the class, many migrant workers were usually a little hesitated when answering their ages. But in the English class, they didn't lie about their birth year (though the age they answered was still the same as they registered). There were two possibilities. One was that in a relaxed and active atmosphere, and in a trust relationship between the teacher and students, they were true to themselves and other people; the other possibility was that they were not so quick in linking these two similar questions. Whichever it was, it at least demonstrated that many of the migrant workers were child labor, working illegally in Baigou Township.

Another case in point was a lesson about workers' daily life. Before we set up the night school, we have done some investigations in Baigou, and the questionnaires suggested that the workers worked 8 hours a day. Nonetheless, in a unit called "My Day", the information I collected was far from what the questionnaire data indicated. The students told me that they woke up at 8 o'clock every morning, went to work without breakfast, had launch in the canteen at 12 o'clock, got back to work and had dinner at 18:30, then continued to work until 11 o'clock or 12 o'clock at night. Most of them had to work about 13 to $14 \mathrm{~h}$ a day. They didn't have weekends, and the only rest time they had was Sunday night from 6 o'clock to 12 o'clock.

In a lesson about family background, I got to know that the majority of the students had two to six brothers and sisters, many of who were also migrant workers in here or other places. In a lesson about shopping, I learned that the workers almost had no money on them, so whenever they needed anything, they borrowed money from their boss and the boss would record their expense and subtract the money from the yearly salary of theirs. The money these migrant workers spent was mostly in buying necessities for living, such as clothes and shoes.

Many people criticize sociological intervention for being too subjective to obtain objective information. But the examples of real age, work hour, family background, etc. have proved them wrong. Not only did we get the true data, but also we dig into what was behind the data.

\section{Reflective Education Method}

Every Friday we departed from Tsinghua University at 2 o'clock pm and arrived at Baigou Township about 4:00 P.M. We would hold a meeting in the hotel lobby around 4:30 P.M. Usually we first summarized the course arrangement and effects of last week, then discussed the class content for that day, outlining the keystones and expected results. Each period before classes began and after classes were over, we asked students about their feelings and suggestions so that we could adjust our 黑 Springer 
courses to fit them better. When the classes of Friday ended, we went back to the hotel and held another meeting, reflecting what happened in the class and collecting feedbacks. Every Saturday afternoon we held a meeting to talk about details of the class that night, and after the classes were over at 9:00 P.M., we still kept discussing class schedule and preparation for next week on our way back to Tsinghua University.

When every session was finished, we held a conference in sociology department, Tsinghua University to summarize the situation, evaluate gain and loss, and discuss education orientation and method for the next session. It was in the ceaseless reflection process that we integrate workers' needs and requests with night school's ultimate goal, making the project more effective.

General Situation, Dilemma and Prospect of Baigou Migrant Worker Night School

Baigou worker night school launched its first class in October 2005 and we have held two trial sessions and a formal session so far.

The first session lasted from October 7th, 2005 to November 5th, 2005. There were 5 weeks and nine classes in total, 240 person-times involved, and 126 people participated in night school courses among which 108 people were workers. The second session lasted from November 18th, 2005 to December 10th, 2005. There were 4 weeks and eight classes in total, 160 person-times were involved, and 87 people participated in night school courses among which 75 people are workers. The third session lasted from May 13th, 2006 to July 27th, 2006. There were 12 weeks and 23 classes in total, 41 relatively stable students participated in the night school, and over 200 person-times were engaged somehow in our night school. Student body was mainly comprised of migrant workers, and others included some factory bosses, local residents, and government officers.

\section{Some Sociological Features of the Students}

Age The migrant workers who came to night school mainly consisted of youths, including a few child labors. What we should pay attention to is that some workers lied about their ages (Table 2).

Gender As presented in Table 3, the ratio of male and female workers was more or less close.

However, regarding the frequency of attending class, it was obvious that female workers had better continuity. Taking the first session for example, about 30 female

Table 2 Age distribution of the workers

\begin{tabular}{llll}
\hline & Under 16 years old & $16-17$ years old & Above 18 years old \\
\hline First session & 3 & 25 & 80 \\
Second session & 2 & 20 & 53 \\
Third session & 1 & 2 & 38 \\
\hline
\end{tabular}


Table 3 Gender of the workers

\begin{tabular}{lll}
\hline & Male workers & Female workers \\
\hline First session & 51 & 57 \\
Second session & 35 & 40 \\
Third session & 17 & 24 \\
\hline
\end{tabular}

workers came to night school over twice, while less than 20 male workers did; moreover, those who had over 4 classes in the night school were practically female workers.

For the first two trial sessions, the times that workers came to have classes were largely dependent on the times their factory participated in night school. And the gender rate or the gender distribution in different sorts of work had great impact on the workers to take part in night school courses. Of course, a discussable hypothesis was that the after-work entertainment of female workers was much less than male workers. Another hypothesis was that female workers had greater enthusiasm in night school than male workers. One instance was, on $21^{\text {st }}$, October (Friday), 20 workers from Liangdian factory came to night school among which 11 out of 13 female workers continued to take courses on Saturday while 1 out of 7 male workers did.

Educational Background Education information is presented in Table 4.

We could see that most workers had been to middle school. But education background could not fairly reflect their English level or computer level. For example, during the first class, a 20-year-old male worker who had graduated from high school was even unable to write the complete 26 English letters out. He honestly confessed that "my high school was a mess-up".

\section{Greatest Feature of the Trial Sessions of Night School: Mobility}

In the trial sessions, the most obvious problem was: the students were mobile and of a small scale. It was mainly because workers there almost had no day-off. Generally, they worked 7 days a week, from morning till late at night, and they often had to work overtime. Therefore, workers had no free time to participate in the night school study, though they showed great interest in our courses. Hence, how to ensure the stability of the students was the major problem.

As in the case of the first session, 108 workers from nine factories took part in the night school study, among which only workers from two factories (Boge and Liangdian) participated in four classes, and workers from other two factories (Yingxia and Kangbei'er) participated in three classes. Whether a factory worker

Table 4 Education background of the workers

\begin{tabular}{llll}
\hline & Elementary school & Middle school & High school \\
\hline First session & 18 & 81 & 9 \\
Second session & 5 & 69 & 1 \\
Third session & 2 & 33 & 6 \\
\hline
\end{tabular}


could and how many times he or she could come to night school was mainly decided by the arrangement of local government. Whether a factory was busy at work was a second determinant. Less than 20 people came to night school more than four times, and most workers only came once or twice. The great mobility of the student was mainly because the production need of a factory could not afford to send its workers to come to night school regularly.

When designing the second session of night school, we already prefigured the problem of great mobility and adopted relevant policy to limit our student to two factories (Starlink and Yingxia). Nonetheless, this idea was still not well realized. In fact, workers from four factories participated in night school among which Liangdian factory and Yingxia factory came three times, and Starlink factory and Huanghaiyuan factory came twice. Twelve workers came more than three times.

Though the second session of night school didn't realize the solidification of factories, a part of the workers still had a full course, especially workers from Liangdian factory. Many of them had come to night school several times during the first session, and with the complementary courses of the second session, many of them were able to get a full night school training course.

To solve the problem of instability, we conceived of three possible solutions. The first was through mobilization in virtue of government power. We intended to select about 20 factories of different scales in town and villages nearby, asking each factory to appoint two workers to take part in a 12-week night school course. Our request was: all the workers appointed must take two nights (about $4 \mathrm{~h}$ ) every weekend to study in the night school for 3 months. There couldn't be any change in workers, and the factories couldn't forbid workers to come for its own reason or deduct the salary of the workers. The advantage of this method was that it could keep the stability of the students. However, its weakness was apparent too. Night school study should be a voluntary thing, and the purpose was to foster workers' autonomy. Using administration power to make the workers come and learn was quite opposite to our goal. Our hope was that workers came and study driven by the administration order, but after 3-month learning in night school, their autonomy would be enhanced.

The second solution was to carry out the night school in the factory. We could move our classes into the factories through negotiation with some big factories. We would educate them on Friday and Saturday nights for $2 \mathrm{~h}$ each. The advantage was that we could avoid making workers come a long way to get to the night school off duty. Simultaneously, we could offer education opportunities to more workers, not limited by those we chose. And the disadvantage of this method was that it might take up workers' rest time, or even annoy them. Also it might bring about the opposition of bosses, for most bosses were unwilling to let outsiders get in to their factories and deal directly with their workers.

Of course we could also experiment the independent recruitment of our night school. We could make advertisement on local television station, and hand out recruitment leaflets in all factories to attract workers to come and study in the night school. The advantage of this method was that we could keep the autonomy of the night school, but it was also risky that we might follow the same old route of the former two sessions.

Among the three possible solutions, according to our understanding of the local situation, we thought the first solution was the most feasible one. Within a regime 
which had kept good continuity as it was before reform, it was almost impossible to escape the influence of power in social life. Therefore, perhaps we should make use of the assistance of power in the first place, and place the hope of fostering the autonomy of workers in the education process of night school.

We had also tried the third option, but it had fallen short of our expectation. Only nine people registered, and two of them were our former students who used to come to the night school and were very active. And as the second option was almost impossible, we had to count on the first one.

To make the first option work, we had done a lot of work in order to improve the recruitment and education of night school. We went to Baoding and Gaobeidian 4 times to communicate with administrators of Baigou Township in hope of their support and help; We went to local factories five times and held discussions with the bosses and workers, explaining to them the night school's education goals and plans in hope of their understanding and participation; The project team held three conferences, and discussed over education method as well as systematic education plan; and we had done training and mobilization for the new members of the project team.

\section{Contrasting Characteristics of Trail and Formal Sessions}

After all the hard work, there were some distinct features of the third session of night school in contrast to the first two trial sessions.

The first was student source. As we planed, we selected 23 factories of different scales in Baigou Township and villages nearby, asking each factory to appoint two workers to take part in the 12-week complete training. In this way, because the number of workers from every factory was relatively small, it wouldn't affect the production of factory which would be acceptable to factory owners. Concrete recruitment was carried out by town government consigned by the project team. We also visited every selected factory and worker on the list provided by town government to make sure that these factories were willing to send their workers to the night school and that these workers themselves were willing to receive training from the night school. Therefore, our students were more stable compared to the last two sessions. However, there were other problems too. One was that because the students were designated by negotiation between government and factory bosses, the workers chosen to come to night school were mostly high-level workers like secretaries, clerks, artificers rather other frontline workers who operated clipping or sewing machines. Another problem was that the workers appointed within one factory were sometimes altered during the process. For example, there was one time at registration, we found out that an old lady came and told us that she was Xiangdong $\mathrm{Wu}$, a young male worker we already knew. We were so surprised that we asked her what was wrong. She confessed that Xiangdong Wu was working overtime and unable to come, so the boss sent her (a relative of the boss) to substitute. What was not so bad was that though many students were high-level workers, they were once frontline workers before promoted to current position, and they still knew what it was like being a bottom worker. Our night school had also attracted some migrant workers from other factories, construction site, and so forth.

暨 Springer 
The second was government support. In the third session, the local government had specially designated two collaborators for us. The two collaborators were officers from economic branch of the local government, one named Chuanbao Zhao, the other named Yongqing Wang. From the first day of the formal session, they had been accompanying our project team to assist the execution of the project. Their major responsibility was to ensure the stability of the student source. Each time about half an hour before our class, they would call the 23 factories selected to confirm that the appointed workers were ready to come. And when we needed to visit these or other factories, they would help lead the way.

The third was class arrangement. This formal session was designed to conduct systematic long-term training for selected migrant workers. The training period was 12 weekends of 3 months, from 7 o'clock to 9 o'clock on Friday and Saturday nights. We required the migrant workers to take part in the 3-month training without any absence. Besides, we paid serious attention to the teachers' recruitment and training. Due to the features of stable student source and long-term training of this session, we required every teacher to make a detailed teaching schedule to insure that we could achieve the goals of systematic training for 12 weekends. Meanwhile, we adjusted teaching content according to real situation to make sure that the migrant workers who received training would be maximally benefited. In the teaching course, we conceived of many means of encouragement. For instance, for students who could keep coming for over 6 weeks, we rewarded them with souvenir of Tsinghua University.

The fourth was organization. In this session, we tried to create a condition for building up an internal organization in the class. Our culminating destination was to foster a civil society whose root was in the self-organization of social groups. Nevertheless, self-organization was often achieved by a conscious group under the advocacy of several militants or leaders. Now that there were no militant yet in the class, the first step of our project should be to cultivate some. Or put it in another way, we needed to impose an external organization structure on the group first so that we could implant the idea of organization into their minds, and then find and raise some militants. First of all, we arranged a computer class early in the third session to make everybody know everybody else in the class. We asked each student to introduce themselves to the class, including their names, place of birth, factory, type of work and interests. And they all had to type their names on the big computer screen in order that all teachers and students could know and remember them easier and quicker. Then after a period of time when students got to know their classmates better, we observed carefully to see among the workers who were relatively more active and militant. Then we brought up the proposal that we would like to elect a monitor and three course delegates (in charge of English, computer and labor law class respectively) to assist our night school operation. The monitor was responsible for helping with registration process, notifying all students of night school news and work schedule, and coordinating relations between teachers and students as well as relations among the students themselves. The course delegate was responsible for handing out relevant materials of each course, helping their fellow classmates with their study and stimulating students to participate in class activities. Some students volunteered to be monitor and course delegates, and others recommended their classmates. The import of class cadre institution had greatly contributed to our project objective. 
The fifth was the night school library. Migrant workers in Baigou were largely cut off from the outside world. This was so because they worked so many hours a day that they didn't have extra time or energy to engage with the outside world; another factor contributing to this was that their work and life was limited within the factory realm that they had few access to the outside world; moreover, their bosses imposed very strict rules on their wages and personal relations that they couldn't afford or had no approaches to get information from the outside world. To change this situation and to provide an opportunity for enriching the workers' knowledge and extending personal relations, we determined to set up a small library in our night school. Through the effort of many volunteers, we collected thousands of books and magazines from teachers and students in Tsinghua University. These books and magazines covered a wide range of areas, including sociology, law, history, literature, fictions, natural sciences, entertainment, to name just a few. We even had a corpus of Shakespeare! The most frequently borrowed books and magazines were news magazines, entertainment magazines, readers' digest, life philosophy and novels. We were also happy to see that some people borrowed books of sociology, law and history (for example, retrospect on cultural revolution in China). Our library was open on every Friday and Saturday, and all migrant workers were welcome to borrow whatever they were interested in for free. Most of the time, our library was crowded with a great many workers from different factories, talking and laughing, building a bridge between migrant workers from diverse backgrounds.

The last was support from outside. Besides the support of the local government, along with teachers and students from Tsinghua University and other institute like Chinese Law Development Support Corporation, we also received support from foreign scholars including Michael Burawoy and You-Tien Hsing from University of California, Berkeley and Mrs. Zhang from ABC. I would like to specially thank Michael Burawoy for his dedicated effort in giving the students a vivid and lively English class with me. His delicate means of teaching had tremendously ignited students' interest of learning English and his bounteous praise of the students' achievement had greatly increased their confidence.

\section{An Unfinished Enterprise}

What we have been doing is an ongoing real utopian project. It is a collective effort to carry out public sociology in the field with strong sociological intervention. However, we are still at a primitive stage in our project and we do have a lot to learn about engaging the publics. As a long-term enterprise, it is hard to say to what degree we have accomplished our original goal. At this moment, what we are able to offer are some readily observable results including:

In respect of skills, through the study in night school, most migrant workers had enhanced their English listening and speaking skills, got to know the basic labor law provisions for protecting their right, and could operate the computer very well. In respect of psychology, they became more confident and ready to express themselves; in respect of social intercourse, they extended their personal relationship realm, and were ready to associate and help workers from other factories.

贯 Springer 
Whether our project will succeed or fail would suggest something valuable for further research. We will keep our passion and hard work in hope of good outcome.

\section{References}

Burawoy, M. (1985). The politics of production: Factory regimes under capitalism and socialism. London: Verso.

Burawoy, M. (2003). For a sociological Marxism: The complementary convergence of Antonio Gramsci and Karl Polanyi. Politics and Society, 31(2), 193-261.

Burawoy, M. (2005a). For public sociology. American Sociological Review, 70, 4-28.

Burawoy, M. (2005b). Third-wave sociology and the end of pure science. The American Sociologist, 152-165.

Burawoy, M. (2005c). The critical turn to public sociology. Critical Sociology, 31(3), 313-326.

Burawoy, M. (2006). A public sociology for human right. Introduction to Judith Blau and Keri Iyall-Smith, public sociologies reader. UK: Rowman and Littlefield.

Chakrabarty, D. (1989). Rethinking working class history. Princeton, NJ: Princeton University Press.

Deutscher, T. (2002). Gazing at the disciplinary bellybutton: A review essay on 'liberation sociology.. Contemporary Sociology, 31(4), 379-382.

Feagin, J. R., \& Vera, H. (2001). Liberation sociology. Boulder, CO: Westview.

Freire, P. (1970). Pedagogy of the oppressed. New York: Continuum.

Hsiao-Chuan, H. (2003). The localization of praxis-oriented research: The case of 'foreign brides literacy programs'. Taiwan: A radical Quarterly in Social Studies, 49, 1-48.

Nee, V., \& Stark, D. (1989). Toward an institutional analysis of state socialism. Remaking the economic institutions of socialism: China and Eastern Europe. Stanford, CA: Stanford University Press.

Polanyi, K. (1944). The great transformation. New York: Farrar and Rinehart.

Shen, Y. (2006a). Social transformation and the re-formation of working class. Sociological Studies, 2, 13-36.

Shen, Y. (2006b). Strong sociological intervention and weak sociological intervention: Two approaches of sociological intervention. Sociological Studies, 5, 1-25.

Sun, L. (2003). Cleavage-Chinese society since 1990s. Beijing: Social Sciences Documentation Publishing House.

Tong, G. (2005). Family factory workers in Bei Township. Collection of Master Dissertation of Peking, Tsinghua and Renmin Univeristy. Shandong: Shandong People's Press.

Touraine, A. (1965). Sociologie de L'Action. Paris: Editions du Seuil.

Touraine, A. (1981). The voice and the eye: An analysis of social movements. Translated by Alan Duff. New York: Cambridge University Press.

Touraine, A. (1987). Return of the actor. Translated by Myrna Godzich and Foreword by Stanley Aronowitz. Minneapolis: University of Minnesota Press. 